\title{
Pemenuhan Hak Konsumen di Institusi Pelayanan Kesehatan di Kota Bandung dan Kota Cimahi
}

\begin{abstract}
Abstrak
Kebijakan pelayanan medis secara legal formal telah memberikan perlindungan hak konsumen kesehatan. Namun, sampai kini belum terungkap upaya institusi pelayanan kesehatan untuk memenuhi dan melindungi hak konsumen kesehatan. Penelitian ini bertujuan mengeksplorasi berbagai kebijakan pemenuhan hak- hak konsumen kesehatan oleh institusi pelayanan kesehatan pemerintah dan swasta. Penelitian yang menggunakan pendekatan kualitatif dengan metode studi ini dilaksanakan pada Agustus 2008 - Januari 2009 di institusi pemerintah RSUD Cibabat-Cimahi, RSKIAAstanaanyar dan Puskesmas Garuda serta institusi swasta RS Muhammadiyah dan RB Barokah. Data dikumpulkan dengan telaah dokumen dan wawancara mendalam terhadap lima orang informan serta dianalisis dengan analisis isi. Hasil penelitian meliputi: tiga institusi pelayanan kesehatan sudah menyusun hak-hak dan kewajiban konsumen kesehatan dan melakukan sosialiasi hak dan kewajiban konsumen kesehatan; telah dikembangkan standar pelayanan, tindakan dan uraian tugas petugas serta kebijakan sistem pembayaran, penyediaan fasilitas dan tenaga; sistem pengaduan pelanggan sudah ada meski belum ada tindak lanjut; forum evaluasi pelanggan belum sinambung serta penghargaan dan sanksi untuk petugas belum jelas.
\end{abstract}

Kata kunci : Kebijakan, pemenuhan hak konsumen, institusi pelayanan kesehatan

\begin{abstract}
This study objective is to explore policies of public and private health care institutions in order to comply consumers rights. This study applies qualitative approach with case study method. This study conducted from August 2008 to January 2009 in three public health care institutions that included Cibabat-Cimahi Hospital, Astanaanyar Mother and Child Hospital and Garuda Public Health Center and two private health care institutions that included Muhammadiyah Hospital and Barokah Birthing Center. Data was collected with indepth interview from 5 informants and policy documents study. Data was analyzed with using content analysis. Results of the study shows that: three health care institutions have already regulated rights and duties of health consumers and two institutions have not have the formal regulation yet; socialization about rights and duties of consumers have been done; health care standard and job descriptions have been regulated; policy of payment system, equipping of facility and personnel have been regulated; there is a system of consumer advocacy but the regulation of follow up has not been clear; Forum of consumer evaluation has not been continued; reward and punishment for providers have not been regulated clearly; the main constraint in the application of regulation is monitoring and evaluation; Documents to comply the rights of consumers have not been completed. There is a necessity to monitor and evaluate implementation of the regulations and also to arrange evaluation of provider performance in application of consumer rights.
\end{abstract}

Key words : policy, compliance of consumer rights, health care institution

*Jurusan Kebidanan Politeknik Kesehatan Departemen Kesehatan Bandung, Jl. Sederhana №.2 Bandung Jawa Barat 40161 (e-mail: ai_arriandhi@yahoo.com) 
Sehat adalah hak asasi manusia. Hak untuk hidup sehat merupakan interaksi dan inter-relasi dari tiga hak dasar manusia yaitu hak pribadi, hak sosial dan hak budaya. ${ }^{1}$ Dalam Undang-Undang Republik Indonesia No. 29 Tahun 2004 tentang Praktik Kedokteran, ${ }^{2}$ dijelaskan kesehatan sebagai hak asasi manusia harus diwujudkan dalam bentuk pemberian berbagai upaya kesehatan kepada seluruh masyarakat melalui penyelenggaraan pembangunan kesehatan yang berkualitas dan terjangkau oleh masyarakat sebagai wujud dari Pasal 20 dan Pasal 21 ayat (1) UndangUndang Dasar Negara Republik Indonesia 1945. Untuk memenuhi hak masyarakat akan kesehatan, pemerintah berkewajiban menyelenggarakan pelayanan kesehatan yang memenuhi syarat. Ada sembilan syarat penyelenggaraan tersebut, yakni tersedia (available), menyeluruh (comprehensive), berkesinambungan (continues), terpadu (integrated), wajar (appropriate), dapat diterima (acceptable), bermutu (quality), tercapai (accessible) serta terjangkau (affordable). Syarat tersebut sama pentingnya, namun terpenuhinya syarat ketersediaan sarana pelayanan kesehatan yang merata, bermutu dan terjangkau merupakan satu keharusan. ${ }^{3}$

Dalam penyelenggaraan pelayanan kesehatan, institusi termasuk tenaga kesehatan (dokter, bidan dan perawat) juga harus memperhatikan prinsip-prinsip hak asasi manusia dalam pelayanan kesehatan. Prinsipprinsip tersebut diantaranya: dignity yaitu hak tidak dianiaya atau diperlakukan dengan cara yang tidak manusiawi, equality yaitu hak tidak dibeda-bedakan dalam menikmati hak-hak asasi manusia, respect yaitu hak dihargai dalam kehidupan pribadi dan berkeluarga, fairness yaitu hak untuk diperlakukan secara adil, dan autonomy yaitu hak mendapatkan penghargaan atas kehidupan pribadi. ${ }^{4}$ Hak asasi manusia dalam bidang kesehatan meliputi the right to health care (hak atas pelayanan kesehatan) yang tertuang dalam konvensi hak sipil dan politik 1966, the right of self determination (hak untuk menentukan nasib sendiri) yang tertuang dalam deklarasi PBB 1948 dan the right to information (hak atas informasi yang benar dan lengkap) yang tertuang dalam deklarasi Helsinki $1964 .^{5}$

Di Indonesia, hak-hak konsumen atas kesehatan sudah diatur cukup rinci dalam undang-undang antara lain Undang-Undang Nomor 8 Tahun 1999 tentang Perlindungan Konsumen, ${ }^{6}$ Undang-Undang Nomor 23 Tahun 1992 tentang Kesehatan, ${ }^{7}$ dan Undang-Undang Nomor 29 Tahun 2004 tentang Praktik Kedokteran. ${ }^{2}$ Dalam undang-undang tersebut juga diatur kewajibankewajiban tenaga kesehatan untuk memenuhi hak-hak konsumen. Dalam memberikan pelayanan, tenaga kesehatan harus memperhatikan harapan-harapan pasien sebagai konsumen. Harapan-harapan tersebut antara lain reliability (kehandalan) yaitu pemberian pelayanan yang dijanjikan dengan segera dan memuaskan, responsiveness (daya tanggap) yaitu membantu dan memberikan pelayanan dengan tanggap tanpa membedakan unsur SARA (Suku, Agama, Ras, Golongan) konsumen kesehatan, assurance (jaminan) yaitu jaminan keamanan, keselamatan dan kenyamanan serta empathy (empati) yaitu komunikasi yang baik dan memahami kebutuhan konsumen/konsumen kesehatan. ${ }^{8}$

Program kebijakan dan manajemen pembangunan kesehatan bertujuan mengembangkan kebijakan dan manajemen pembangunan kesehatan guna mendukung penyelenggaraan sistem kesehatan nasional dengan kebijakan pokok antara lain adalah pengkajian dan penyusunan kebijakan. ${ }^{9}$ Kebijakan pelayanan medis secara legal formal tercantum dalam berbagai peraturan perundang-undangan telah memberikan perlindungan pada hak konsumen kesehatan. Akan tetapi, sampai saat ini belum banyak diungkap upaya-upaya apa yang dilakukan institusi pelayanan kesehatan untuk memenuhi dan melindungi hak konsumen kesehatan. Untuk itu, perlu dilakukan studi untuk mengeksplorasi kebijakankebijakan institusi pelayanan kesehatan dalam upaya pemenuhan hak- hak konsumen kesehatan juga tenaga kesehatan serta kelengkapan dokumen dalam upaya pemenuhan hak-hak konsumen di institusi pelayanan kesehatan publik maupun swasta seperti azas hak konsumen kesehatan dalam pelayanan sehari-hari, standar profesi dan standar prosedur operasional serta kelengkapan kebutuhan medis termasuk cara rujukan bila tidak mampu melakukan suatu pemeriksaan atau pengobatan.

\section{Metode}

Penelitian ini menggunakan pendekatan kualitatif dengan metode studi kasus untuk mengeksplorasi kebijakan dalam pemenuhan hak-hak kosumen di bagian bersalin institusi pelayanan kesehatan publik maupun swasta. Penelitian dilaksanakan dari Agustus 2008 sampai Januari 2009. Tempat penelitian adalah tiga institusi pelayanan kesehatan milik pemerintah (CibabatCimahi, RSKIA Astanaanyar dan Puskesmas Garuda) dan dua institusi pelayanan kesehatan milik swasta (RS Muhammadiyah dan RB Barokah). Sumber dan jenis data adalah kata-kata informan dan yang tertulis adalah dokumen kebijakan. Informan adalah para stakeholder di institusi pelayanan kesehatan yang menjadi tempat penelitian (Lihat Tabel 1).

Penelitian ini menggunakan data primer dan data sekunder. Data primer adalah hasil wawancara dengan informan dan data sekunder adalah hasil telaah dokumen. Teknik pengumpulan data dengan wawancara dan observasi terstruktur kelengkapan dokumen yang mendukung pemenuhan hak-hak konsumen di 5 institusi tersebut. 
Tabel 1. Profil Informan

\begin{tabular}{lll}
\hline Nama & \multicolumn{1}{c}{ Institusi } & \multicolumn{1}{c}{ Jabatan } \\
\hline $\mathrm{A}$ & RSKIA Astanaanyar & Ka seksi Pelayanan Medik \\
$\mathrm{M}$ & RSU Cibabat & Ka Bid keperawatan \\
$\mathrm{W}$ & Puskesmas Garuda & Ka TU \\
$\mathrm{N}$ & RS Muhammadiyah & Ka Bid Keperawatan \\
$\mathrm{O}$ & RB Barokah & Pemilik RB \\
& & \\
\hline
\end{tabular}

Instrumen yang digunakan adalah peneliti, pedoman wawancara dan daftar tilik dokumen. Alat bantu yang digunakan dalam wawancara adalah alat perekam suara. Tahapan dalam mengolah dan menganalisis data sebagai berikut: transkripsi data: catatan dan rekaman diketik secara lengkap sesuai kata perkata seperti apa adanya. Juga dicatat kegiatan non-verbal selama wawancara berlangsung dan mengamati bagaimana tingkah laku dan emosi informan pada saat memberikan jawaban atau penjelasan tentang objek penelitian. Pengorganisasian data: mencatat tanggal pengumpulan data dan menandai data setiap informan dengan menggunakan angka atau kode. Pengenalan: membaca kembali data, membuat memo dan rangkuman; dan koding: pengkategorian data dengan membuat matriks berdasarkan tema yang sudah ditentukan. Analisis data menggunakan pendekatan analisis isi. Setelah diolah dan dianalisis data hasil penelitian disajikan dalam bentuk narasi dan kutipan. Dalam penelitian ini dilakukan interpretasi data untuk memperoleh arti dan makna yang lebih mendalam dan luas terhadap hasil penelitian. Pembahasan hasil penelitian dilakukan dengan cara membandingkan hasil penelitian dengan teori yang relevan.

\section{Hasil}

Kendala

Penelitian ini menghadapi beberapa kendala terutama sulitnya waktu untuk wawancara karena banyak kesibukan sehingga ada beberapa diwakilkan stakeholder lain, tetapi dengan kepastian penggantinya menguasai substansi yang diwawancarakan. Selain itu, ada retensi keterbukaan akan informasi, terkesan sangat hati-hati dalam menguraikan kebijakan-kebijakan penerapan hakhak konsumen kesehatan.

\section{Hak-hak dan Kewajiban Konsumen Kesehatan}

Uraian tentang hak-hak dan kewajiban konsumen kesehatan di tempat penelitian, tiga institusi yaitu RSU Cibabat, RSKIA Astanaanyar dan RS Muhammadiyah sudah memilikinya. Uraian hak-hak dan kewajiban konsumen kesehatan tersebut disusun oleh institusi dengan mengacu pada undang-undang yang berlaku. Hal ini berbeda dengan dua institusi yang lain yaitu Puskesmas Garuda dan RB Barokah. Di kedua institusi ini, hak-hak dan kewajiban konsumen kesehatan belum diuraikan secara rinci. Mengenai sosialisasi hak-hak dan kewajiban konsumen kesehatan, semua institusi mengaku sudah melakukannya.

\section{Upaya Memenuhi Hak Konsumen}

Institusi pelayanan kesehatan sudah melakukan berbagai upaya untuk memenuhi hak-hak konsumen kesehatan antara lain dengan penyusunan standar pelayanan dan tindakan. Di RSU Cibabat, RSKIA Astanaanyar dan RS Muhammadiyah, Standar Operasional Prosedur (SOP) untuk pelayanan dan tindakan sudah tersusun dengan baik. Tetapi di RB Barokah, belum semua standar tersedia. Sedangkan, di Puskesmas Garuda belum ada satu pun standar pelayanan yang tersusun. Institusi pelayanan juga sudah menyusun uraian tugas petugas, membuat sistem pembayaran yang mempermudah konsumen mendapat pelayanan kesehatan. Untuk meningkatkan kualitas pelayanan dilakukan dengan upaya penyediaan institusi dan tenaga baik jumlah maupun kualifikasi.

Institusi pelayanan kesehatan sudah melakukan berbagai upaya untuk memenuhi hak-hak konsumen kesehatan antara lain dengan Penyusunan Standar Pelayanan dan Tindakan. Standar Operasional Prosedur untuk pelayanan dan tindakan di RSU Cibabat, RSKIA Astanaanyar dan RS Muhammadiyah sudah tersusun dengan baik. Sementara, untuk di RB Barokah belum semua standar tersedia. Sedangkan, di Puskesmas Garuda karena belum ada satu pun Standar Pelayanan. Hal ini salah satunya karena perpindahan ruang bersalin pada waktu renovasi puskesmas, sehingga standar-standar yang sudah ada tercecer dan belum ditata kembali. Selain itu, dalam rangka memenuhi hak-hak konsumen kesehatan sebagai konsumen dan sebagai arahan bagi petugas terutama bidan dan perawat dalam bekerja, institusi pelayanan kesehatan juga sudah menyusun uraian tugas. Uraian tugas yang merupakan pernyataan tertulis yang menguraikan fungsi-fungsi, tugas-tugas, tanggung jawab, wewenang, kondisi kerja dan aspek-aspek pekerjaan tertentu dan lainnya. Uraian tugas ini akan menjadi acuan bagi petugas dalam melaksanakan pekerjaannya sehari hari.

\section{Sistem Pengaduan Pelanggan}

Berdasarkan hasil wawancara empat institusi tempat penelitian sudah memiliki sistem pengaduan pelanggan. Mekanisme pengaduan dari pelanggan dapat disampaikan secara lisan (langsung) ataupun secara tertulis. Institusi juga sudah menyediakan kotak saran, ataupun buku dan juga layanan sms untuk menyampaikan aduan atau keluhan berkaitan dengan pelayanan yang diterima. Keluhan itu disampaikan ke bagian Quality Assurance atau Humas rumah sakit sedangkan Puskesmas karena lingkupnya lebih kecil semua bentuk pengaduan, lisan 
maupun tertulis ditujukan langsung ke kepala puskesmas. Sistem pengaduan pelanggan ini, belum tersedia di RB Barokah. Tindak lanjut keluhan pelanggan kepada petugas dilakukan sesuai aturan disiplin pegawai yang tahapannya akan dimulai dengan teguran lisan dan kalau tidak berhasil baru diberikan teguran tertulis, demikian ada jenjang dalam penerapan dispilin tersebut. Tetapi informan mengakui tindak lanjut ini sering tidak jelas dalam aplikasinya.

\section{Forum Evaluasi Pelanggan}

Berdasarkan hasil wawancara, forum evaluasi ini sudah ada tetapi belum berjalan dengan baik. Evaluasi yang diadakan lebih bersifat evaluasi pencapaian program (bersifat kuantitas) tetapi belum menyentuh sisi konsumen kesehatan sebagai konsumen institusi kesehatan (kualitas pelayanan yang diterima konsumen). Forum evaluasi pelanggan sangat penting untuk diadakan disetiap institusi pelayanan kesehatan untuk mengetahui kinerja layanan institusi kesehatan tersebut dari sudut pandang konsumen kesehatan sebagai pengguna. Tidak adanya forum evaluasi pelanggan akan membuat pihak institusi pelayanan kehilangan arah, apa sebenarnya yang diinginkan pelanggan yang seharusnya dipenuhi oleh pihak institusi. Berdasarkan hasil wawancara, di institusi yang menjadi tempat penelitian, forum evaluasi ini sudah ada tetapi belum berjalan dengan baik. Selain itu, evaluasi yang diadakan lebih bersifat evaluasi pencapaian program (bersifat kuantitas) tetapi belum menyentuh sisi konsumen kesehatan sebagai konsumen institusi kesehatan. Sehingga, wajar kalau pihak institusi menganggap tidak ada masalah dengan pelanggan (dalam hal ini konsumen kesehatan) karena melihat cakupan pertolongan persalinan terus meningkat setiap tahunnya.

\section{Penghargaan dan Sanksi untuk Petugas}

Di institusi pelayanan kesehatan pemerintah, kebijakan tentang penghargaan dan sanksi sehubungan dengan penerapan hak-hak konsumen ini belum ada. Kebijakan yang berlaku sekarang pemberian jasa kepada bidan, perawat atau tenaga lain baru berdasarkan golongan, jabatan serta beban kerja dan risiko kerja. Misalnya yang bekerja di ruang tindakan persalinan, unit gawat darurat, ruang bedah itu memiliki poin yang lebih tinggi dibanding yang bertugas di bagian perawatan dan klinik karena memang beban kerja dan risiko kerja mereka lebih besar dan itu berdampak terhadap insentif yang diterima. Namun, untuk penilaian kinerja seperti pegawai yang rajin dan malas, judes dan ramah belum ada perbedaan dalam insentif yang diterima. Hal tersebut disebabkan oleh aturan penilaian kinerja yang belum disusun. Selain itu, ada berbagai penghargaan lain yang diberikan sebagai hak-hak pegawai yang sudah diatur dalam peraturan, seperti hak atas gaji, cuti, tunjangan tambahan penghasilan yang besarnya disesuaikan dengan golongan. Di institusi pemerintah ada perbedaan kebijakan antara puskesmas dan rumah sakit. Di puskesmas ada jasa pertolongan persalinan bagi bidan, sedangkan di rumah sakit tidak ada. Kebijakan tentang sanksi untuk petugas lebih mengacu kepada aturan sanksi untuk pegawai tetapi belum secara rinci mengatur sanksi bagi petugas yang tidak memenuhi hak konsumen kesehatan. Di institusi pelayanan swasta ada perbedaan, di rumah sakit penghargaan diberikan kepada petugas berbentuk promosi jabatan yang akan berdampak terhadap insentif yang diterima. Di RB Barokah, penghargaan diberikan sama rata dan sanksi jarang sekali diberikan kecuali kepada petugas yang benar-benar bermasalah.

\section{Kendala Penerapan Kebijakan}

Kendala penerapan kebijakan ini adalah evaluasi dan monitoring yang lemah sehingga, meskipun aturan sudah banyak dibuat tetapi jarang yang terkoreksi penerapannya karena hasil pelaksanaan yang tidak dimonitor dan dievaluasi. Dampak kebijakan akan terasa jika diterapkan dan penerapan akan sinambung apabila ada monitoring pelaksanaan. Evaluasi terhadap kebijakan yang ada harus dilakukan untuk meningkatkan kualitas pelayanan. Kelemahan dalam kebijakan tentang penerapan hak-hak konsumen di institusi kesehatan adalah evaluasi dan monitoring pelaksanaan kebijakan tersebut.

\section{Kelengkapan Dokumen}

Telaah dokumen penunjang penerapan hak-hak konsumen di institusi kesehatan menunjukkan bahwa untuk di Puskesmas Garuda belum ada satu pun SOP dalam bentuk buku ataupun yang tempalkan di ruang VK maupun di ruang nifas. Formulir evaluasi pelanggan tidak tersedia, rekam medis dalam disimpan di laci meja selama periode satu bulan, setelah itu disimpan oleh bidan dalam lemari. Tetapi, tidak ada petunjuk penyimpanan rekam medis yang tertulis. Pedoman yang ada di puskesmas hanya petunjuk pengelolaan alat bahan habis pakai, deskripsi persyaratan Jamkesmas, daftar harga kelas perawatan dan uraian tugas petugas. Di RSU Cibabat, hampir semua dokumen sudah ada kecuali SOP konseling sebelum dan sesudah tindakan dan kode etik memelihara kerahasiaan. Sedangkan, di RSKIA Astanaanyar semua dokumen sudah ada kecuali kode etik memelihara kerahasiaan. Di RS Muhammadiyah hampir semua dokumen sudah lengkap kecuali untuk konseling sebelum dan sesudah tindakan serta kode etik memelihara kerahasiaan. Di RB Barokah, SOP untuk tindakan, daftar berbagai alat yang ada di ruangan sesuai dengan kebutuhan tindakan, kartu dan buku data konsumen kesehatan serta daftar harga kelas perawatan sudah ada. Namun, dokumendokumen lain seperti formulir informed consent, evaluasi kepuasan pelanggan, dan lain-lain, belum lengkap. 


\section{Pembahasan}

Berbagai hak dan kewajiban konsumen kesehatan telah diuraikan di dalam berbagai aturan seperti UndangUndang Kesehatan, Undang-Undang Praktik Kedokteran. Selain itu, hak-hak konsumen tersebut juga diatur dalam Undang-Undang Perlindungan Konsumen. Khusus untuk hak-hak wanita bersalin, IBI sebagai organisasi profesi juga sudah menguraikannya. Hak-hak konsumen kesehatan sebagai konsumen di institusi pelayanan kesehatan antara lain meliputi: hak mendapatkan pelayanan yang manusiawi; hak mendapatkan informasi yang jelas tentang penyakit yang diderita, tindakan medis yang akan dilakukan dan kemungkinan timbul penyulit akibat tindakan tersebut, alternatif pengobatan lain, prognosis atau perjalanan penyakit serta perkiraan biaya pengobatan; hak untuk memilih dokter yang merawat; hak untuk menolak tindakan yang dilakukan terhadap dirinya; hak mengakhiri pengobatan dan rawat inap atas tanggung jawab sendiri; hak atas privasi dan kerahasiaan penyakit yang diderita; hak meminta dokter yang merawat berkonsultasi dengan dokter lain; hak didampingi keluarga pada saat kondisi kritis; hak marahasiakan penyakitnya kepada orang atau pihak lain; hak untuk menjalankan ritual agama dan kepercayaannya di rumah sakit selama tidak mengganggu pengobatan konsumen kesehatan yang lain; hak memperoleh asuhan perawatan yang bermutu baik; hak untuk mengajukan keluhan-keluhan dan memperoleh tanggapan segera; hak atas rekam medik; hak untuk memeriksa dan menerima penjelasan pembayaran; hak memilih sarana kesehatan. ${ }^{8,10}$ Standar sangat penting untuk ditetapkan karena standar dapat meningkatkan efisiensi dan mengarahkan pada pemanfaatan sumber daya dengan lebih baik. ${ }^{11}$

Hak konsumen kesehatan di institusi bersalin meliputi: hak memperoleh informasi tentang tata tertib dan peraturan yang berlaku; hak atas pelayanan yang manusiawi, adil dan jujur; hak memperoleh pelayanan kebidanan sesuai dengan profesi bidan tanpa diskriminasi; hak memilih bidan yang akan menolong sesuai dengan keinginannya; hak mendapatkan informasi yang meliputi kehamilan, persalinan, nifas dan bayinya yang baru dilahirkan; hak mendapat pendampingan suami atau keluarga selama proses persalinan berlangsung; hak memilih dokter dan kelas perawatan sesuai dengan keinginannya dan sesuai dengan peraturan yang berlaku; hak dirawat dokter yang bebas menentukan pendapat kritis dan pendapat etis tanpa campur tangan pihak luar; hak meminta konsultasi dokter lain yang terdaftar terhadap penyakit yang diderita dengan sepengetahuan dokter yang merawat; hak meminta privasi kerahasiaan penyakit yang diderita termasuk data-data medis; hak mendapat informasi tentang penyakit yang diderita, tindakan kebidanan yang akan dilakukan, alternatif terapi lain, prognosis dan perkiraan biaya pengobatan; hak menyetujui/ memberi- kan izin terhadap tindakan yang akan dilakukan sehubungan dengan penyakit yang diderita; hak menolak tindakan yang hendak dilakukan serta mengakhiri pengobatan dan perawatan atas tanggung jawab sendiri setelah memperoleh informasi yang jelas tentang penyakit; hak didampingi keluarga dalam keadaan kritis; hak menjalankan ibadah sesuai agama/kepercayaan yang dianut, selama tidak mengganggu konsumen kesehatanyang lain; hak atas keamanan dan keselamatan diri selama dalam perawatan; hak menerima atau menolak bimbingan moril maupun spiritual; hak mendapatkan perlindungan hukum atas terjadinya kasus malpraktik. ${ }^{2}$

Di institusi pelayanan kesehatan, hak-hak tersebut dirumuskan ulang sesuai dengan kebijakan setempat. Tiga institusi sudah menguraikannya secara tertulis sedangkan dua institusi belum menguraikan secara tertulis. Alasan puskesmas karena masih dalam penataan sedangkan alasan RB Barokah karena lingkupnya kecil dan petugasnya sedikit dan dianggap semua petugas sudah mengetahui hak-hak konsumen kesehatan yang harus dipenuhi.

Supaya hak-hak dan kewajiban konsumen kesehatan yang sudah tersusun dilaksanakan maka harus dilakukan sosialisasi kepada pasien maupun kepada petugas. Sosialisasi sudah dilakukan kepada pasien dengan cara hak-hak dan kewajiban konsumen kesehatan tersebut dipampang di setiap ruangan sedangkan kepada petugas dilakukan pada saat rapat atau pertemuan-pertemuan pemberitahuan lisan maupun berbentuk edaran.

Salah satu upaya yang harus dilakukan oleh institusi pelayanan kesehatan untuk memenuhi hak-hak konsumen kesehatan adalah memfasilitasi sistem pembayaran. Dalam kebijakan yang dibuat, ada perbedaan antara institusi kesehatan pemerintah dan institusi kesehatan swasta. Di institusi kesehatan pemerintah kebijakan sistem pembayaran ini sebagian besar sudah ditetapkan dari pemerintah setempat. Sedangkan di institusi swasta ditetapkan oleh institusi sendiri. Fasilitas yang memadai merupakan salah satu dari hak-hak konsumen kesehatan yang harus dipenuhi. Fasilitas tersebut berupa ruangan yang memadai untuk beristirahat, kebersihan dan juga ketersediaan alat dan bahan yang dibutuhkan. Di institusi kesehatan pemerintah penyediaan fasilitas tergantung pada pemenuhan pengajuan oleh pihak dinas kesehatan pemerintah daerah setempat. Di institusi kesehatan, mekanisme tidak berbeda, institusi menginventarisasi kebutuhan kemudian mengajukan ke dinas sedangkan apabila di institusi swasta diajukan ke direksi sedangkan di RB Barokah kebijakan ditetapkan sendiri oleh pemilik dengan mendapat masukan dari bidan atau perawat yang bekerja.

Hak-hak konsumen kesehatan akan dapat dipenuhi jika tenaga yang tersedia memadai baik dalam jumlah dan kualifikasi. Di institusi kesehatan pemerintah, upaya penyediaan tenaga tersebut dilakukan lewat pengajuan ke 
dinas dan pengadaanya tergantung kebijakan dinas setempat. Status kepegawaian petugas terbagi atas Pegawai Negeri Sipil (PNS), tenaga kontrak atau disebut sukwan DKK dan sukwan rumah sakit atau puskesmas. Di RS Muhammadiyah, pengadaan merupakan kebijakan institusi dengan melihat hasil analisis kebutuhan tenaga. Sementara di RB Barokah, tidak ada standar dan acuan yang jelas untuk pengadaan pegawai. Ketersediaan tenaga di bagian bersalin, semua institusi secara umum menyatakan sudah memadai, tetapi dalam kenyataannya sering ada kendala karena petugas tidak selalu lengkap karena tugas lain, sekolah, cuti atau urusan lain.

Pengaduan pelanggan seharusnya tersedia di setiap institusi pelayanan kesehatan untuk menjamin bahwa setiap hak-hak konsumen kesehatan dilindungi. Tindak lanjut penanganan pengaduan pelanggan adalah upaya yang seharusnya dilakukan untuk meningkatkan kualitas pelayanan terhadap konsumen. Selain itu, juga memperbaiki citra institusi kesehatan di masyarakat pengguna. Institusi tempat pelayanan mengakui belum ada tindak lanjut yang jelas untuk setiap keluhan pelanggan yang masuk. Secara konsep, keluhan konsumen kesehatan akan berhubungan dengan disiplin PNS, jadi tahapannya akan dimulai dengan teguran lisan dan kalau tidak berhasil baru diberikan teguran tertulis, demikian ada jenjang dalam penerapan dispilin tersebut. Tindak lanjut yang belum jelas ini disebabkan oleh anggapan belum pernah ada kasus fatal dalam pelayanan yang diberikan oleh petugas.

Penghargaan dan sanksi merupakan upaya yang dilakukan untuk memotivasi petugas kesehatan untuk meningkatkan kinerja menjadi lebih baik. Ada berbagai kriteria yang dapat diberikan penghargaan misalnya disiplin, keterampilan mengerjakan tindakan, keramahan dan lain-lain. Penghargaan dapat diberikan dalam bentuk materi seperti pemberian insentif atau juga non materi seperti promosi jabatan tertentu. Berdasarkan pemaparan dari para stakeholder, dapat disimpulkan bahwa kebijakan tentang penghargaan dan sanksi penerapan hakhak konsumen tersebut belum ditetapkan secara jelas. Hal ini dapat disebabkan oleh belum ada aturan tentang penilaian kinerja yang ril dalam penerapan hak-hak konsumen kesehatan.

Selain itu, terkait dengan tindak lanjut pengaduan pelanggan yang belum jelas dan evaluasi pelanggan yang belum kontinu. Padahal penilaian kinerja pemberi pelayanan sangat penting untuk meningkatkan kualitas pelayanan, karena kinerja pelayanan merupakan faktor penting upaya peningkatan kualitas kesehatan penduduk. Selain itu, karyawan medik, paramedik, dan karyawan lain merupakan aset terpenting rumah sakit yang harus diberdayakan. Mutu proses pelayanan kesehatan hanya akan dapat meningkat kalau karyawan mempunyai komitmen dan kompeten dalam pekerjaan. ${ }^{13}$
Padahal, evaluasi merupakan bagian yang penting dari proses manajemen karena akan diperoleh umpan balik terhadap program atau pelaksanaan kegiatan. ${ }^{14}$ Evaluasi adalah suatu proses untuk menilai atau menetapkan sejauh mana tujuan yang telah ditetapkan tercapai. Evaluasi juga merupakan proses membandingkan antara hasil yang telah dicapai oleh suatu program dengan tujuan yang direncanakan. ${ }^{15}$ Kegiatan evaluasi itu mencakup langkah-langkah: menetapkan atau memformulasikan tujuan, menetapkan kriteria, menetapkan cara atau metode evaluasi, menentukan keberhasilan program serta menyusun rekomendasi atau saran-saran tindakan lebih lanjut terhadap program berikutnya berdasarkan hasil evaluasi tersebut. ${ }^{14}$ Evaluasi suatu program kesehatan masyarakat dilakukan terhadap tiga hal, yakni evaluasi terhadap proses pelaksanaan program, evaluasi terhadap hasil program dan evaluasi terhadap dampak program.

Dalam program kesehatan masyarakat, juga dilakukan pemantauan program yang merupakan kegiatan observasi yang berlangsung terus-menerus untuk memastikan dan mengendalikan keserasian pelaksanaan program dengan perencanaan yang telah ditetapkan. Monitoring dilakukan sejalan dengan evaluasi, dengan tujuan agar kegiatan-kegiatan yang dilakukan dalam rangka mencapai tujuan program tersebut berjalan sesuai dengan yang direncanakan, baik waktunya maupun jenis kegiatannya. Pada hakikatnya evaluasi diyakini sangat berperan dalam upaya meningkatkan kualitas operasional suatu program dan berkontribusi penting dalam memandu pembuat kebijakan di seluruh strata organisasi dengan menyusun, mendesain evaluasi yang baik dan menganalisis hasilnya dengan tajam, kegiatan evaluasi dapat memberi gambaran tentang bagaimana kualitas operasional program, layanan, kekuatan dan kelemahan yang ada, efektifitas biaya dan arah produktif potensial masa depan. Dengan menyediakan informasi yang relevan untuk pembuat kebijakan, evaluasi dapat membantu menata seperangkat prioritas, mengarahkan alokasi sumber dana, menginstitusi modifikasi dan penajaman struktur program dan aktifitas serta memberi sinyal akan kebijakan penataan ulang personil dan sumber daya yang dimiliki. Di samping itu, evaluasi dapat dimanfaatkan untuk menilai dan meningkatkan kualitas serta kebijakan program. ${ }^{16}$

\section{Kesimpulan}

Untuk memenuhi hak konsumen kesehatan maka institusi terkait sudah menyusun standar pelayanan dan tindakan serta uraian tugas. Agar pelayanan kesehatan terjangkau oleh semua lapisan masyarakat, institusi pelayanan kesehatan sudah membuat kebijakan sistem pembayaran yang mempermudah konsumen. Untuk meningkatkan kualitas pelayanan, institusi juga mengupayakan penyediaan institusi dan juga penyediaan tenaga. Sistem pengaduan pelanggan sudah ada tetapi belum ada tindak 
lanjut yang jelas. Forum evaluasi pelanggan belum kontinyu. Penghargaan dan sanksi untuk petugas dalam penerapan hak konsumen kesehatan belum ada. Kendala yang paling utama dalam penerapan kebijakan hak konsumen kesehatan adalah dalam monitoring dan evaluasi. Dokumen-dokumen untuk memenuhi hak konsumen kesehatan sebagian sudah ada tetapi ada beberapa yang masih belum lengkap.

\section{Saran}

Untuk meningkatkan kualitas pelayanan kesehatan dalam memenuhi hak-hak konsumen kesehatan maka perlu adanya kebijakan yang mendukung. Kebijakan akan berdampak bila direalisasikan. Untuk itu, perlu adanya monitoring yang terus-menerus dalam pelaksanaan kebijakan tersebut. Evaluasi atas kebijakan yang sudah dibuat juga merupakan hal yang penting dilakukan untuk perbaikan kebijakan yang ada. Institusi pelayanan kesehatan perlu menyusun penilaian kinerja petugas dalam penerapan hak-hak konsumen sebagai landasan dalam memberikan penghargaan dan sanksi kepada petugas sehingga petugas termotivasi untuk memberikan pelayanan yang terbaik bagi konsumen.

\section{Daftar Pustaka}

1. Moeloek AF. Pembangunan berkelanjutan dalam peningkatan derajat kesehatan manusia (pendekatan pada paradigma sehat). [diakses tanggal 04 Januari 2008]. Diunduh dari: www. Ifip.org

2. Undang-Undang No. 29 Tahun 2004 tentang Praktik Kedokteran.
3. Depkes RI. Sembilan syarat penyelenggaraan pelayanan kesehatan yang baik. [diakses tanggal 12 Januari 2008]. Diunduh dari: www.depkes.go.id

4. The British Institute of Human Rights, Department of Health. Human rights in healthcare- a framework for local action. [diakses tanggal 24 Maret 2008]. Diunduh dari: www.bihr.org

5. Sunarto. HAM dan pelayanan kesehatan. [diakses tanggal 04 Januari 2008]. Diunduh dari: www.fkui.org

6. Undang-undang Nomor 8 Tahun 1999 tentang Perlindungan Konsumen.

7. Undang-undang Nomor 23 Tahun 1992 tentang Kesehatan.

8. Perlindungan konsumen kesehatan berkaitan dengan malpraktik medik. [diakses tanggal 25 Januari 2008]. Diunduh dari: http://pkditjenpdn.go.id

9. Gunnara H. Perlindungan hak pasien di RS Kanker Dharmais Jakarta. Jurnal Kesehatan Masyarakat Nasional. 2007;2(3):136-43.

10. Djojosugito A. Kebijakan pemerintah dalam bidang pelayanan kesehatan menyongsong AFTA. [diakses 25 Pebruari 2008]. Diunduh dari: www.pdpersi.co.id

11. Pusdiklat SDM Kesehatan bekerja sama dengan Dit. Bina Pelayanan Keperawatan; Depkes RI. Manajemen kinerja klinik perawat bidan (penyusunan standar dan SOP). Jakarta: Depkes RI; 2004.

12. IBI. 50 tahun Ikatan Bidan Indonesia. Jakarta; 2002.

13. Adisasmito W. Sistem kesehatan. Jakarta: Raja Grafindo Perkasa; 2007.

14. Notoatmodjo S. Prinsip-prinsip dasar ilmu kesehatan masyarakat. Cetakan ke-2. Jakarta: Rineka Cipta; 2003.

15. Razak A. Kajian asuransi kesehatan (kasus RSUD Wangaya, Bali). [diakses tanggal 11 Pebruari 2009]. Diunduh dari: http://lkpk.org

16. Ristek. Panduan monitoring dan evaluasi riset unggulan terpadu. [diakses 3 Januari 2009]. 